\title{
COMMENT
}

\section{EVIDENCE: JUDGMENTS AND PLEAS IN PRIOR CRIMINAL PROSEGUTIONS AS EVIDENCE IN GIVIL ACTIONS}

\begin{abstract}
Although a plea of guilty in a prior criminal prosecution was admissible at common law, the record of the judgment was not admissible as evidence of the facts upon which it was based. ${ }^{1}$ This exclusionary rule, based on technicalities, has been widely criticized. The facet of the rule which excludes prior criminal convictions is gradually being eroded; the rule as to acquittals, however, remains unchanged.
\end{abstract}

\section{Convictions}

Many courts today still hold that a criminal conviction is not admissible in a subsequent civil action as evidence of the facts upon which the judgment was rendered. ${ }^{2}$ Various rationalizations have been offered for this position. One reason frequently advanced for the exclusion of prior convictions is the maxim res inter alios acta, ${ }^{3}$ the belief being that something done between two parties should not operate to the disadvantage of a third. ${ }^{4}$ However, as can readily be seen, this is not a

\footnotetext{
${ }^{1}$ Smith v. Rummens, I Camp. N.P. 9, I70 Eng. Rep. 858 (K.B. I807) (Lord Ellenborough); The King v. Warden of the Fleet, I2 Mod. Rep. 337, 88 Eng. Rep. 1363 (K.B. 1700); 2 FREEMAN, JUDGMENTS $\& 653$ (5th ed. 1925) [heremafter cited as FREEMAN].

${ }^{2}$ E.g., Silva v. Silva, 297 Mass. 217,7 N.E.2d 6ox (1937); Girard v. Vermont Mut. Ins. Co., I03 Vt. 330, 154 Atl. 666 (I93I); Interstate Dry Goods Stores v. Williamson, 9I W.Va. I56, II2 S.E. 301 (x922) (dictum); Hollington v. F. Hewthorn \& Co. [1943] I K.B. 587. See generally, JONES, EVIDENCE \& 639 (5th ed. I958); MCCormick, Evidence \& 295 (1954); Phipson, Evidence 407 (8th ed. I942); 2 Wharton, Criminal EVIDENCE $\$ \S 634-644$ (Izth ed. I955); 4 Wigmore, EVIDENCE $\& 1346 a$ (3rd ed. 1940) [hereinafter cited as Wigmore]; 5 Wigmore $\S$ I67ra. A conviction is, however, admissible to establish the fact of conviction, Brown v. Bradlee, 156 Mass. 28, 30 N.E. 85 (1892) (action on contract for reward offered for evidence leading to arrest and conviction), or to attack the credibility of a witness. 4 WIGMORE $§ 980$.

${ }^{3}$ See generally Cowen, The Admissibility of Criminal Convictions in Subsequent Civil Proceedings, 40 CaIIf. L. Rev. 225 (I952).

'E.g., Balestreiri v. Arques, 49 Cal. App. 2d 664, 222 P.2d 277 (r942); Doyle v. Gore, I5 Mont. 212, 38 Pac. 939 (1895); Interstate Dry Goods Stores v. Williamson, 9r W.Va. I56, x 12 S.E. 30I (I922); Hollington v. F. Hewthorn \& Co. [1943] I K.B. $5^{87}$. This reasoning would be valid where the plaintiff in the civil action seeks
} 
valid ground for the exclusionary rule. The introduction of the prior conviction operates to the disadvantage of the defendant in the criminal suit rather than the one who was not a party.

Two other justifications frequently given for excluding the convictions are lack of mutuality ${ }^{5}$ and the different standards of proof in criminal and civil suits. ${ }^{b}$ The latter is clearly inapplicable since the facts upon which the conviction was based were established beyond a reasonable doubt, while in the subsequent civil litigation, only a preponderance of the evidence is required. The lack of mutuality objection has no validity for the same reason. The rationale of this objection is that the record of conviction should not be admissible as evidence of the facts upon which it was based because the accused, if found innocent, could not have introduced the record of acquittal as evidence of his innocence. The fallacy of this sophism is apparent-an acquittal is merely a finding that guilt has not been established beyond a reasonable doubt, while the plaintiff in the civil action need only prove fault by a preponderance of the evidence. Thus a rule admitting a conviction and excluding an acquittal would not be an unwarranted discrimination between the plaintiff and the defendant, but rather a recognition of the difference in probative value of the evidence.

to introduce the conviction of a third party as evidence of the liability of the defendant, Lipman Bros. Inc. v. Hartford Acc. \& Indm. Co., 149 Me. 199, 10o A.2d 246 (1953), or where the defendant attempts to introduce the conviction of a third party in order to defeat plaintiff's claim. Bibbs v. Fidelity Health \& Acc. Co., $7 \mathbf{r}$ S.W.2d ${ }_{764}$ (Mo. Ct. App. 1934), Warren v. Pilot Life Ins. Co., 215 N.C. 402, 2 S.E.2d I7 (1939).

'E.g., Beckworth v. Phillips, 6 Ga. App. 859, 65 S.E. 1075 (1909); Silva vo Silva, 297 Mass. 217,7 N.E.2d 6or (1937) ; Girard v. Vermont Mut. Fire Ins. Co., 103 Vt. 330, 154 Atl. 666 (1931); Aetna Cas. \& Sur. Co. v. Anderson, 200 Va. 385, 105 S.E.2d 869 (1958) (dictum). And see cases cited in 2 FreEMaN $\$ 654$ n.17.

${ }^{6}$ E.g., New York Life Ins. Co. v. Murdaugh, 94 F.2d 104 (4th Cir. 1938) (dictum); Seaboard Air Line Ry. v. O'Quin, 124 Ga. 357, 52 S.E. 427 (1905); Wilson v. Manhatten Ry. 2 Misc. 127, 20 N.Y. Supp. 852, aff'd 144 N.Y. 632, 39 N.E. 495 (1894); Interstate Dry Goods Stores v. Williamson, 91 W.Va. 156, 112 S.E. 301 (1922). And see cases cited in 2 FreEMAN $\$ 654 \mathrm{n} .4$.

${ }^{7}$ Any policy upon which the res judicata doctrine of mutuality is founded is clearly inapplicable here because of the different standards of proof. Moreover, even in a res judicata situation some courts have abandoned the requirement of mutuality and confined the requirement of privity to the party against whom the plea of res judicata was made. See Davis v. Mckinnon \& Mooney, 266 F.2d 87o (6th Cir. 1959); Bernhard v. Bank of America Nat'l Trust \& Sav. Ass'n, 19 Cal.2d 807, 122 P.2d 892 (1942); Currie, Mutuality of Collateral Estoppel: Limits of the Bernhard Doctrine, 9 Stan. L. Rev. 281 (1957); Polasky, Collateral Estoppel-Effects of Prior Litiga- 
Convictions have also been excluded on the grounds that their admission would violate the opinion and hearsay rules. ${ }^{8}$ Although it is true that a conviction and judgment are based on hearsay and the opinion of the jury, the logical outcome of this reasoning would result in also precluding introduction of judgments in prior civil actions and would therefore undercut the whole doctrine of res judicata. The fact that numerous cases have admitted prior convictions indicates that these objections are not insurmountable obstacles to the admission of such evidence. $^{9}$

Some courts have rejected rigid adherence to the general exclusionary rule and instead have inquired into the seriousness of the crime involved and the proposed use of the conviction in the civil action. ${ }^{10}$ In effect, these courts distinguish between defensive and offensive utilization of the conviction. The former involves using the conviction to defeat an action later brought by the convicted person or his privy; the latter involves its use by a plaintiff as evidence of the fault of the convicted person.

\section{Defensive Use and the Schindler Rule}

Some courts, unable to accept the anomalous result of one's obtaining an advantage or profit from his own wrongdoing as shown by the conviction, have evolved the rule that a conviction is admissible when introduced to prevent a criminal from enforcing a claim arising out of his crime.11 This rule and the tests for it were carefully analyzed in

tion, 39 Iowa L. REv. 217 (1954). But see Restatement, JUdGMENTs $\$ 93$ $(1942)$.

${ }^{8}$ Hollington v. F. Hewthorn \& Co., [1943] I K.B. $5^{87}$. But see Hinton, Judgment of Conviction-Effect in a Civil Case as Res Judicata or as Evidence, 27 ILI. L. REv. 195 (1932) (feels that hearsay and opinion objections justify exclusion).

- The hearsay and opinion objections would appear to be merely technical obstacles; if they were valid the same reasoning would apply to exclude official reports.

The hearsay obstacle is easily surmounted since the party against which the conviction is offered was present at the criminal trial, was confronted with the witnesses and had the right to cross-examine. Wigmore states that "the opinion rule . . . is not intrinsically applicable here." 5 WIGMORE $\S 1671 a$ at 689 . See generally Comment, 2x CAN. B. REv. 658 (r943).

10 " $[\mathrm{A}] \mathrm{n}$ enlightened conscience does not permit us to cling to the archaic rule of complete exclusion for all purposes when such a fact has been solemnly and judicially determined. Greater weight is to be given to this conclusion when the fact of guilt is established beyond a reasonable doubt in a trial in which the accused is surrounded by all of the safeguards afforded by law." North River Ins. Co. v. Militello, Ioo Colo. 343, 347, 67 P.2d 625, 626 (1937).

${ }^{11}$ Maybee v. Avery, 18 Johns. 352 (N.Y. 1820), was one of the earliest decisions 
Schindler v. Royal Insurance Company. ${ }^{12}$ The court there held that the prior conviction was admissible against a convicted arsonist who was attempting to recover on an insurance policy covering the goods which he had been convicted of burning. The court not only rejected the exclusionary rule, but further held that the conviction was prima facie evidence of the facts upon which it was based. The Schindler decision has been followed in many jurisdictions. ${ }^{13}$ Some courts, however, have regarded the prior conviction only as some evidence of guilt, ${ }^{14}$ and others have deemed it to be conclusive, hence barring the subsequent plaintiff. ${ }^{15}$

There can be no doubt that the Schindler rule is more logical than the traditional exclusionary rule. A person convicted of a serious crime has had both an opportunity and a motivation to defend and has had his guilt established beyond a reasonable doubt. The obvious social policy served by refusing to allow a criminal to profit by his crime

advancing this rule.

"The rule of exclusion is a shield for the protection of those who have had no opportunity to assert their defense. To apply it here would be to convert it into a sword in the hands of one who has had such opportunity, to be used by him for the effectuation of the same fraud which has been established." Eagle, Star \& British Dominions Ins. Co. v. Heller, 149 Va. 82, 106, 140 S.E. 314, 321 (1927).

${ }^{2} 258$ N.Y. 310,179 N.E. 711 (1932).

${ }^{28}$ E.g., New York \& Cuba Mail S.S. Co. v. Continental Ins. Co., 32 F. Supp. 251 (S.D.N.Y. 1940); Sovereign Camp, Woodmen of the World v. Gunn, 229 Ala. 508, I58 So. 192 (1934); North River Ins. Co. v. Militello, soo Colo. 343, 67 P.2d 625 (1937).

However, some jurisdictions still follow the exclusionary rule in this situation. E.g., Silva v. Silva, 297 Mass. 217, 7 N.E.2d 60I (1937); Lillie v. Modern Woodmen of America, 89 Neb. 1 , 130 N.W. 1004 (I9Ix); Girard v. Vermont Mut. Fire Ins. Co., I03 Vt. 330, I54 Atl. 666 (I93 I).

The English courts followed the admissibility rule for a time, Mash v. Darley, [IgI4] I K.B. I; In Re Crippen, [IgII] P. I08; but reverted to the exclusionary rule, Hollington v. F. Hewthorn \& Co., [1943] I K.B. 587, although that case involved offensive use of the conviction.

${ }_{14}$ E.g., Fidelity-Pheonix Ins. Co. v. Murphy, 226 Ala. 226, 166 So. 604, cert. denied, 299 U.S. 557 (1936); Douglas v. Central of Ga. Ry. Co., 48 Ga. 427,172 S.E. 828 (Ct. App. 1934); Hardeman v. Georgia Power Co., 42 Ga. App. 435, 556 S.E. 642 (193I); Wolff v. Employers Fire Ins. Co., 282 Ky. 824, 140 S.W.2d 640 (1940); Osborne v. People's Benev. Industrial Life Ins. Co., I91 La. App. 667, 139 So. 733 (Ct. App. 1932).

${ }_{15}$ Austin v. United States, 125 F.2d 816 (7th Cir. 1942); Mineo v. Eureka Security Fire \& Marine Ins. Co., I82 Pa. Super. 75, 125 A.2d 612 (1956); Poston v. Home Ins. Co., 191 S.C. 314, 4 S.E.2d 261 (1939); Eagle, Star \& British Dominions Ins. Co. v. Heller, 149 Va. 82, 140 S.E. 314 (1927). Wigmore apparently favors admission of the conviction, but would not make it conclusive. 4 WIGMORE $\S 1346 a$. 
would seem far to outweigh technical obstacles to the admission of such evidence. Undoubtedly a final judgment of conviction should be given some weight in a subsequent civil suit. ${ }^{16}$

Although the same considerations which permit admission of the prior conviction logically would render such evidence conclusive against the subsequent plaintiff, it is doubtful, as a practical matter, if many jurisdictions will break this far from tradition. Furthermore, such. treatment of the conviction denies the convicted party an opportunity to show a prior miscarriage of justice. The prima facie rule of the Schindler case serves to soften the break with the traditional view by permitting an explanation of the conviction.

\section{Offensive Use}

Where a conviction is offered as evidence of the fault of a convicted person defending a subsequent civil suit, the technicalities of the traditional rule have prevailed over logical analysis. Here the vast majority of the courts still hold that the plaintiff in the civil suit cannot introduce the record of the defendant's conviction as evidence of the facts upon which it was based. ${ }^{17}$

The Schindler rule, admitting prior convictions for defensive purposes, developed as a reaction to the possibility of allowing a criminal to reap the benefits of his crime. However, where the offensive use

${ }^{x 0} \mathrm{~A}$ conviction from which an appeal is pending is not admissible in the subseguent civil action as evidence of the facts involved. E.g., Stinson v. Richardson, $239 \mathrm{Ala}$. 16x, 194 So. 508 (1940); McCauley v. Stone, 3 I5 S.W.2d 476 (Mo. Ct. App. 1958); Marshak v. City of Long Beach, 195 Misc. 125, 81 N.Y.S.2d 74 (Sup. Ct. 1948); Pendleton v. Norfolk \& W. Ry., 82 W. Va. 270 , 95 S.E. 94x (x9 8 ).

However, unless an appeal has the effect of setting aside or suspending the judgment of conviction, the pendency of an appeal does not preclude the showing of such conviction as bearing ou the credibility of a witness. E.g., Ringer v. State 137 Tex. Crim. 242, x29 S.W.2d 654 (1938); Burford v. Commonwealth, I79 Va. 752, 20 S.E.2d 509 (1942).

${ }^{17}$ E.g., Burbank v. McIntyre, 135 Cal. App. 482, 27 P.2d 400 (1933); Montgomery v. Crum, 199 Ind. 660, 16I N.E. $25 x$ (x928); Pugaczewska v. Maszko, I64 Md. 355, I63 Atl. 205 (x932); Nowak v. Orange, 349 Pa. 217, 36 A.2d 78x (1944). Of course the judgment in the criminal action is competent evidence of its own rendition. Burt v. Union Central Life Ins. Co., 187 U.S. 362 (1902). And a judgment is admissible for purposes of impeachment. MCCormick $\S 43$.

Statutes sometimes play an important role in the admissibility of prior convictions. Section 5 of the Clayton Act provides for the admission of a prior criminal conviction in a subsequent suit as evidence of the facts. 69 Stat. 283 (1955), I5 U.S.C. § 16 (1958), amending 38 Stat. 73I (1914). See Emich Motors Corp. v. General Motors Corp., 340 U.S. $55^{8}\left(\mathbf{1 9 5}^{\circ}\right)$. For further examples of similar statutes see OHIO REV. CODE ANN. \$ I.x6 (Page 1953) and statutes cited at note 24 infra. 
of the conviction is attempted these policy factors are not so evident; consequently, the exclusionary rule has retained much of its force, with the courts relying on the traditional grounds. ${ }^{18}$ Thus the propriety of permitting offensive use of prior convictions turns on whether the plaintiff should be aided in imposing on the defendant the civil consequences of his criminal act.

A growing minority of jurisdictions have become dissatisfied with the bases of the majority rule. These courts have insisted that common sense and consistency of adjudication require that the judgment of conviction, when offered against the person convicted as evidence of the facts upon which it was based, be admitted. ${ }^{10}$ A person accused of a serious crime, it would seem, is motivated to put forth the best possible defense. Consequently, a conviction following such a defense would have sufficiently probative value to be considered by the trier of fact in a subsequent civil action. ${ }^{20}$ This view is embodied in the Uniform Rules, which provide that a conviction for a felony is admissible. ${ }^{21}$

Even those courts which allow a prior conviction as evidence of the facts upon which it was rendered generally do not permit a conviction for a traffic offense to be shown. ${ }^{22}$ The validity of the rule ex-

${ }^{18}$ Thus according to the majority, a conviction of contempt for failure to comply with an injunction is not admissible in a subsequent suit for damages for noncompliance with the injunction. America Fire Protection Serv. v. Williams, 17 I Cal. App. 2d 397, 340 P.2d 644 (1959). Contra, Giessler v. Accurate Brass Co., 271 App. Div. 980, 68 N.Y.S.2d I (1947). And it has been held that in a wrongful death action the plaintiff cannot introduce the conviction of the defendant for manslaughter. Moyle v. Brown, 133 Colo. 29, 290 P.2d 1105 (1955). It should be pointed out that the Moyle case may be of doubtful value as precedent, for the court based its decision upon the rule that a traffic conviction is not admissible in a subsequent civil suit. This would seem to be faulty reasoning since the reason for excluding traffic convictions does not apply to the exclusion of convictions for serious crimes. See notes 23-27 infra and accompanying text. In the recent case of Trust Co. v. Pollard, 256 N.C. 77, 123 S.E.2d 104 (1961), the North Carolina Supreme Court held, in effect, that defendant's prior conviction of manslaughter was not admissible in a subsequent wrongful death action. Applying the "general and traditional" rule, the court granted a motion to strike plaintiff's allegation of defendant's prior conviction.

${ }^{10}$ E.g., Page v. Skinner, 220 Ala. 302, 125 So. 36 (1929); Bankston v. Folks, 38 La. Ann. 267 (1886); Wald v. Wald, 161 Md. 493, 159 Atl. 97 (1931); Smith v. Minnissale, 190 Misc. I14, 75 N.Y.S.2d 645 (Sup. Ct. 1947); Bealor v. Hahn, 132 Pa. 242, 19 Atl. 74 (1890). Accord, Greenwell's Adm'r v. Burba, 298 Ky. 255, 182 S.W.2d 436 (1944).

20 "Probably the trend of evolution will be toward the admission generally against a present party of any judgment or finding in a former civil or criminal case if the party had an opportunity to defend." MCCORMICK, EvidENCE $\$ 295$ at 619 (1954).

${ }^{21}$ UNIFORM Rule OF Evidence 63(20) (1953).

${ }^{22}$ E.g., Moseley v. Ewing, 79 So. 2 d 776 (Fla. 1955); Padgett v. Williams, 82 
cluding a traffic conviction has been widely recognized ${ }^{23}$ and codified by statutes in some states. ${ }^{24}$ The most potent argument for exclusion stems from the very nature of traffic court proceedings. They are conducted with less deliberation and care ${ }^{25}$ than proceedings in ordinary criminal prosecutions, and moreover, defendants in traffic cases usually do not defend with the same zeal as those in a serious criminal trial. ${ }^{28}$

The exclusion of traffic convictions, either under the traditional rule $^{27}$ or as an exception to the Schindler rule, does have some validity. However, it is difficult to see. why a person accused of a serious crime should not be held bound or at least affected by the result of a conviction, regardless of whether the conviction is sought to be used offensively or defensively. The safeguards' afforded the accused are greater in the criminal trial and he has had ample opportunity to establish his defense before the criminal tribunal. Therefore, he would not be prejudiced by the admission of such evidence.

Ga. App. 509, 61 S.E.2d 676 (1950); Walther v. News Syndicate Co., 276 App. Div. r69, 93 N.Y.S.2d 537 (1949) (well reasoned opinion); Smith v. New Dixie Lines, 2oI V2. 466, I1 I S.E.2d 434 (1959); Forney v. Morrison (I Io S.E.2d 840 (W.Va. I959).

Some courts do allow the traffic conviction to be shown for impeachment purposes. E.g., Fisher v. Gunn, 270 S.W.2d 869 (Mo. 1954); Clinger v. Duncan, I 66 Ohio St. 216,141 N.E.2d 156 (1957). It has also been held that admission of the conviction for such a purpose is within the trial court's descretion. Zeller v. Mayson, I68 Md. 663, I79 Atl. I79 (1935). Of course a party cannot impeach his own witness by showing his traffic conviction. Eisenhower v. Baltimore Transit Co., rgo Md. 528,59 A.2d 323 (1948).

38 The drafters of the Uniform Rules of Evidence have expressed their realization of the unreliability of traffic convictions as a resolution of the facts involved:

Despite the logic of this theory there is widespread opposition to opening the door to let in evidence of convictions particularly of traffic violations in actions which later develop over responsibility for damages. In other words, trials and conviction in traffic courts ... often do not have about them the tags of trustworthiness as they often are the result of expediency or compromise. To let in evidence of conviction of a traffic violation to prove negligence and responsibility in a civil case would seem to be going too far and for that reason this rule limits the admissibility of judgments of conviction under the hearsay exception to convictions of a felony.... UNIFORM RuLE of Evidence 63 (20), comment (1953).

${ }^{34}$ E.g., Colo. Rev. Stat. ANn. $\$$ 13-4-140 (1953); IOWA COde ANn. $\$ 321.489$ (I946); Minn. Stat. ANN. $\$$ 169.94 (1945); S.C. Code $\$ 46-686$ (I952); UTAH CODE ANN. \$ 4I-6-I 7o (1953).

${ }^{25}$ In 1936 one New York judge heard 1,016 traffic cases in 2 hours. WARREN, Traffic Courts 112 (1942).

${ }^{30}$ Richardson, Evidence 335-6 (8th ed. I958), as quoted in Ando v. Woodberry, 9 App. Div. 2d 125, I3 I, I92 N.Y.S.2d 414, 420 (1959).

${ }^{27}$ See note 2 supra and accompanying text. 


\section{Acouitrals}

The majority of courts are agreed that an acquittal is inadmissible as evidence of innocence in a subsequent civil action. ${ }^{28}$ These courts soundly recognize that an acquittal signifies only that guilt was not established beyond a reasonable doubt and does not preclude a finding of guilt by the mere preponderance of the evidence. ${ }^{29}$ Thus, for example, a judgment of acquittal does not bind the prosecuting government in a later civil suit between it and the accused where the standards of proof differ ${ }^{30}$ Similarly, an acquittal of arson is inadmissible in a subsequent suit to recover on an insurance policy covering the burned goods. ${ }^{31}$ Although it has been argued that the acquittal should be admissible as having some tendency to prove that the defendant was not guilty, ${ }^{32}$ the danger that a jury might easily exaggerate

${ }^{28} E$.g., Stone v. United States, 167 U.S. 178 (1897); Williams v. Cambridge Fire Ins. Co., 230 F.2d 293 (5th Cir. x956); Wirt v. Fraser, 30 So. 2 d 174 (Fla. I947); Clough v. Greyhound Corp., 91 Ga. App. 246, 85 S.E.2d 476 (1954); Tennessee Odin Ins. Co. v. Dickey, x9o Tenn. 96, 228 S.W.2d 73 (1950). Contra, Wolff v. Employer's Fire Ins. Co., 28z Ky. 824, 140 S.W.2d 640 (1940) (dictum).

In a civil action growing out of a traffic accident evidence that driver of vehicle was not arrested is not admissible, Eggers v. Phillips Hardware Co., 88 So. $2 d 507$ (Fla. 1956), nor is evidence that a driver was arrested admissible, Burge v. House, 94 Ohio App. 515, 110 N.E.2d 425 (1952). By the same token it is reversible error to admit into evidence the record of dismissal of a criminal complaint. Ethridge v. City of New York, x2x N.Y.S.zd xo3 (Sup. Ct.), aff'd, 283 App. Div. 867, 129 N.Y.S.2d 915 (1954).

However, an acquittal may be introduced, if relevant, as evidence of its rendition. Western Union Tel. Co. v. Thomasson, $25 \mathrm{I}$ F. 833 (4th Cir. 1918) (action for malicious prosecution).

${ }^{20}$ The difference in the standard of proof required precludes application of the doctrine of res judicata as a bar to civil suit subsequent to an acquittal in a criminal prosecution. United States v. National Ass'n of Real Estate Bds., 339 U.S. 485 (1950); Helvering v. Mitchell, 303 U.S. 391 (1938).

Although an acquittal on a criminal charge is not a bar to a subsequent civil action, remedial in its nature, arising out of the same facts, where the object of the subsequent action is punishment the acquittal is a bar; to entertain the second proceeding for punishment would subject defendant to double jeopardy. Murphy v. United States, 272 U.S. 630 ( 1926 ) (subsequent suit remedial in nature); Coffey v. United States, 116 U.S. 436 ( 1886 ) (subsequent suit punitive in natnre).

${ }^{30}$ United States v. National Ass'n of Real Estate Bds., 339 U.S. 485 (1950), Stone v. United States, 167 U.S. 178 (1897); Murray \& Sorenson, Inc. v. United States, 207 F.2d 119 (1st Cir. 1953); United States V. Gramer, 19 I F.2d 74I (9th Cir. 195I); United States v. United States Gypsum Co., 5I F. Supp. 613 (D.D.C. 1943).

${ }_{81}$ Tennessee Odin Ins. Co. v. Dickey, s9o Tenn. 96, 228 S.W.2d 73 (1950).

${ }^{32}$ Bush, Criminal Convictions as Evidence in Civil Proceedings, 29 MIss. L.J. 276, 278 (1958). At least one court has allowed the acquittal to be shown as tending to 
the probative weight of an official judicial record of acquittal, despite proper instruction, would seem to require exclusion.

\section{Pleas}

A plea of guilty to a criminal offense is admissible in a later civil action on the theory that it is an admission by the party who entered the plea. ${ }^{33}$ This reasoning permits the introduction of the plea even though it is later withdrawn. ${ }^{34}$ The convicted party has, however, an opportunity to explain the circumstances under which the plea was made. 35

Generally speaking, absent statute, the courts will permit plaintiffs to introduce a plea of guilty by the alleged tortfeasor to a charge of traffic violation predicated upon the same collision. ${ }^{36}$ Here again strict

support a conclusion of innocence. Patterson v. Commonwealth, 187 Va. 913, 48 S.E.2d 357 (1948).

${ }^{33}$ E.g., Davis v. Aetna Life Ins. Co., 279 F.2d 304 (9th Cir. I960); Motley v. Page, 250 Ala. 265, 34 So. 2d 201 (1948); Vaughn v. Jonas, 3I Cal. 2d 586, 19 I P.2d 432 (1948). But see True v. Citizens' Fund Mut. Ins. Co., I87 Minn. 636, 246 N.W. 474 (1933).

Most courts say the plea is admissible but the conviction is not. E.g., Piechota v. Rapp, ${ }_{4} 8$ Neb. 443,27 N.W.2d 682 (1947). Wigmore belittles this, referring to it as a "tweedle-dee and tweedle-dum distinction." 4 Wigmore $\$ 1346 a$ n.1. Practically, the distinction is not sound, for to admit the plea is virtually the same as to inform the jury of the conviction.

${ }^{84}$ Morrissey v. Powell, 304 Mass. 268, 23 N.E.zd $4 \times 1$ (1939). Contra, Kercheval v. United States, 274 U.S. $220\left(x_{927}\right)$. However, evidence of a withdrawn plea of guilty is insufficient to establish fault without additional evidence. People $v$. Steinmetz, 240 N.Y. 41 I, I48 N.E. 597 (1925).

${ }^{85}$ E.g., Odian v. Habernicht, ${ }_{33}$ Cal. App. 2 d 193, 283 P.2d 756 (D. Ct. App. 1955); Race v. Chappell, $304 \mathrm{Ky} .788,202$ S.W.2d 626 (1947); Miuasian v. Aetna Life Ins. Co., 295 Mass." I, 3 N.E.2d 17 (1936); Berlin v. Berens, 76 S.D. 429, 80 N.W.2d 79 (1957). Contra, Marcazzolo v. Lawrence, 20 Misc. 2d 31, 191 N.Y.S.2d 872 (Sup. Ct. I 959 ).

${ }^{30}$ E.g., Miller v. Blanton, 2 10 S.W.2d 293 (Ark. 1948); Kock v. Elkins, 7 x Idaho 50, 225 P.2d 457 (1950); Weiss v. Wasserman, 91 N.H. r64, I5 A.2d 861 (1940); Stanton v. Major, 274 App. Div. 864, 82 N.Y.S.2d 134 (1948); Keely v. Arkansas Motor Freight Lines, 278 S.W.2d 765 (Mo. 1955). But see, Zenuk v. Johnson, I I4 Conn. 383 , I58 Atl. 9 ro (1932); Baird v. Boger, z87 Ore. 131, 210 P.2d 118 (1949). Contra, Michitsch v. Stimfel, 7 Misc. 2d 960, 164 N.Y.S.2d 246 (Sup. Ct. 1957); Max v. Brookhaven Development Corp., 262 App. Div. 907, 28 N.Y.S.2d 845 (194I).

The mere mailing in of a fine does not constitute a plea of guilty, Mooneyhan v. Benedict, 284 S.W.2d $74 x$ (Tex. Civ. App. 1955), and a forfeiture of a bond after a charge of traffic violation is not an admission and therefore is not admissible for impeachment purposes. Stover v. Yoakum, rog N.E.2d 877 (Ohio Ct. App. 1952); Sherwood v. Murray, 233 S.W.2d 879 (Tex. Civ. App. 1950). But failure to 
adherence to traditional rules without examining the policies behind such rules has lead to an undesirable rigidity which ignores practical realties. A plea of guilty to a criminal offense is generally admissible because as a practical matter it does have some probative value, in that a person prosecuted for a serious crime is generally motivated to put forth the best possible defense. However, this analysis is patently inapplicable in the situation involving a traffic offense, for here the accused motorist normally has little incentive to defend vigorously. From a practical standpoint a plea of guilty to a traffic offense has no more, probably less, probative value than a conviction for a traffic offense following a plea of not guilty. A court is ignoring the realities of the situation if it says that a plea of guilty to such a charge is a solemn confession by the one entering the plea and therefore should be admitted in evidence. ${ }^{37}$ It is apparent that motorists often plead guilty to charges of traffic violation for a variety of reasons when they actually believe themselves to be innocent. ${ }^{38}$

Although many courts have indicated that the defendant may explain

appear on the return day of the warrant is viewed as a plea of guilty. Lamb v. Butlex, 198 Va. 509, 95 S.E.2d 239 (1956).

${ }^{87} \mathrm{~A}$ New York judge is reported as having said:

You have about as much chance of getting justice in a traffic court as that smoke ring has of making a loop over the nose of the man in the moon. That court is a madhouse, a disgrace to any civilized community. Defendants frequently are considered guilty before their cases are called. Often they are lined up in front of the bar and fined collectively. Few of them get genuine hearings. There is no time for individual treatment. Most of the defendants plead guilty and get out of the crush as soon as possible. Others go the limit in getting some politician to try to fix their cases. The tragic part is that the majority of the better class citizens get their only impression of the operation of the judiciary in traffic courts. Compare, Telling It to the Judge, 84 Forum 79-85 (Aug. 1930) as quoted in WARREN, TrafFic COURTS $8 \mathrm{n.3}$ (1942).

${ }^{38}$ Reasons why a plea of guilty may be entered are, for example, the saving of time, the avoidance of inconvenience and unfavorable publicity, the realization that the contest is hopeless for lack of witnesses, and the probability that punishment will be substantially less after a plea of guilty.

The probative value of a plea of guilty to a charge of traffic violation is even more debatable in a jurisdiction where the plea of nolo contendere has been abolished. Where a person has had an opportunity to plead nolo contendere and has instead entered a plea of guilty, the plea would seem to have some value worth considering by the trier of fact. But absent the plea of nolo contendere the accused must plead guilty or not guilty to the traffic violation. Since no moral turpitude is attached to a conviction for a traffic violation, there is no substantial incentive for the motorist to attempt to plead and prove his innocence. 
the circumstances under which the plea was entered, ${ }^{39}$ the problem is obviously not solved by shifting the inquiry to the jury. Such evidence is highly prejudicial and when admitted has in all probability such weight with the jury that any seeming privilege of rebuttal is nugatory. ${ }^{40}$ It seems patently unfair, therefore, to admit the plea as evidence of the facts upon which it was based where the punishment following such a plea is slight, especially when compared with the inconvenience of trial, and where there is some likelihood that the plea was entered as a mere compromise. However, absent statutes ${ }^{41}$ the courts have admitted pleas of guilty to traffic offenses, acknowledging no difference between such a prosecution and one for a more serious crime.

The courts generally have held that a plea of nolo contendere, while admitting guilt for purposes of the action in which it is entered, restricts its effect to that action and is not admissible in a civil suit as evidence of the facts admitted by the plea. Such a plea merely represents the failure of the defendant to resist his conviction as vigorously as possible; it is a limited admission made solely for the purpose of the indictment and has no further operat:on. ${ }^{42}$

${ }^{80}$ E.g., Ando v. Woodberry, 8 N.Y.2d 165, 168 N.E.2d 520 (1960). And see cases cited in note 35 supra.

${ }^{10}$ Cammarano v. Gimino, 234 Ill. App. 556 (1924).

${ }^{42}$ As stated above in note 24 and accompanying text, some states have passed statutes prohibiting the use of prior traffic convictions. In at least four of these jurisdictions the statute has been construed as excluding a plea of guilty to a traffic offense. Ripple v. Black, 132 Colo. 125, 286 P.2d 625 (1955); Tucker v. Heaverlo, 249 Iowa 197, 86 N.W.2d 353 (1957); Warren v. Marsh, 215 Minn. 615, II N.W.2d 528 (1943); Utah Farm Bureau Ins. Co. v. Chugg, 6 Utah 2d 399, 315 P.2d 277 (1957).

A New York statute provides that " $a$ traffic infraction is not a crime and the punishment imposed therefore shall not be deemed for any purpose a penal or criminal punishment and shall not affect or impair the credibility as a witness or otherwise of any person convicted thereof." N.Y. VEHICLE \& TRAFfiC LAW § 155 . The New York courts have held that this statute renders inadmissible, as proof of the facts upon which it was based, a conviction of a traffic violation following a plea of not guilty. Walther v. News Syndicate Co., 276 App. Div. 169, 93 N.Y.S.2d 537 (1947). However, they have held that the statute does not render inadmissible a conviction of a traffic offense based on a plea of guilty. Ando v. Woodbury, 8 N.Y.2d 165,168 N.E.2d 520 (1960).

${ }^{12}$ E.g., Federal Deposit Ins. Corp. v. Cloonan, 165 Kan. 68, 193 P.2d 658 (1951) State v. Fitzgerald, 140 Me. $3^{14}, 37$ A.2d 799 (1944). Nor is the conviction after the plea admissible as evidence of the facts. Teslovich v. Fireman's Fund Ins. Co., I Io Pa. Super. 245, 168 Atl. 354 (1933), even where there is a statute providing that a final judgment is admissible. Twin Ports Oil Co. v. Pure Oil Co., 26 F. Supp. 366 


\section{Conclusion}

While the law has remained virtually unchanged as to the admissibility of pleas of guilty and acquittals, there is a definite trend toward positing the admissibility of prior convictions upon their proposed use, resulting in the admission of prior convictions only for defensive purposes. This trend is desirable to the extent that it abrogates the exclusionary rule. However, the distinction drawn by many courts between offensive use and defensive use is not a sound one. A prior criminal conviction has the same probative value whether used offensively or defensively. Sound logic and public policy have led many courts to admit a conviction where it is sought to be used defensively; the same logic should lead them to admit the conviction where it is sought to be used offensively. However, this is not to say that all convictions should be admissible. There are some situations, for example, traffic convictions, where the exclusionary rule does achieve desirable results, although for independent reasons.

A rule of admissibility for convictions of serious crimes, and a rule of exclusion for convictions which have little probative value, ${ }^{48}$ is preferable as grounded in the actual realities of criminal judicial enforcement. These practical rules would aid in effectuating the public policy of putting an end to litigation but would not impinge on the convicted person's right to "one day in court."

(D. Minn. 1939). It has been held that a conviction after a plea of nolo contendere is admissible for impeachment purposes. State v. Herlihy, 102 Me. 310, 66 Atl. 643 (1906). See generally, Lenvin \& Meyers, Nolo Contendere: Its Nature and Implications, 51 YALE L.J. 1255 (1942).

${ }^{43}$ MODEL CODE OF EVIDENCE rule 521 (1942) provided that all judgments of crimes or misdemeanors were admissible. UNIFORM RULES OF EvidENCE 63 (20) (1953) states that only convictions for felonies are admissible. And see 50 Colum. L. REv. 529 (1950).

"Much is needed in order to reshape the law of evidence to the requirements of the society of our times. To put the matter in genexal terms, it is not organized upon rational guiding principles and is embarrassed by multiplicty of inflexible detained rules. What the prnciples should be may be put thus: Everything offered in evidence logically contributing toward proof of a matter required to be established to maintain a claim or defense in the case should be admitted unless a well recognized ground of policy or of law calls for excluding it and nothing offered is to be received unless it is logically probative of such matter." 5 POUND, JURISPRUDENCE, 584-85 (1959). 